\title{
The Ecosystem Approach and Public Engagement in Ocean Governance: The Case of Maritime Spatial Planning
}

\author{
Antonia Zervaki*
}

Introduction

The concept of ocean governance entails complex multilevel relations and processes through which 'individuals and institutions, public and private', attempt to manage maritime affairs, accommodate diverse interests and cooperate through formal or informal arrangements. ${ }^{1}$ The spectrum of issues falling under the general rubric of 'ocean governance' is extremely broad. It encompasses different sectoral policies, ranging from maritime transport, fisheries and the exploitation of marine resources to marine environmental protection, blue energy or underwater cultural heritage. Additionally, ocean governance implicates different levels of decision-making (international, regional, national and sub-national) and involves various actors that either take part in decision-making processes or are affected by them, including national and local authorities, international organizations, private companies, NGOs, local communities and individuals.

The ecosystem approach to ocean governance has brought to the fore these complex interrelations since it emphasizes the need for comprehensive management schemes in ocean affairs; it constitutes a holistic approach to ocean affairs management that attempts to accommodate environmental with societal objectives, including the participation of stakeholders and local communities in the design, implementation and adaptive processes of such plans.

* The author would like to cordially thank the editors of this volume for their kind invitation and their comments.

1 Based on the definition of global governance provided by Commission on Global Governance, Our Global Neighborhood, <http://www.gdrc.org/u-gov/global-neighbourhood/> accessed on 5 November 2016. 
Maritime Spatial Planning (MSP) constitutes an integrated management process that has gained significant momentum during the last decade. ${ }^{2}$ Initially introduced in the domain of environmental protection, it has gradually evolved into a multipurpose and multilevel organizational framework, and thus a useful ocean micro-governance model, ${ }^{3}$ founded on the ecosystem-based approach. MSP is aimed at the comprehensive management of different - often conflicting - uses and the preservation of the natural processes of marine space. What is interesting in the case of MSP is that it entails a significant degree of societal engagement in its different phases of development and implementation. This societal engagement is made increasingly challenging with the gradual shift of focus from national to regional MSP ventures, ${ }^{4}$ and to its implementation in areas beyond national jurisdiction. ${ }^{5}$

2 This is reflected in the UN Secretary General's Reports on Oceans and the Law of the Sea since 2007. See <http://www.un.org/depts/los/general_assembly/general_assembly_reports .htm> accessed on 6 November 2016, as well as in the contribution of international or regional organizations, such as UNESCO or the EU and state practice, see S Jay and others, 'International Progress in Marine Spatial Planning' (2013) 27 Ocean Yearbook 171.

3 In political science literature the concept of micro-governance reflects the division of labor among the institutional arrangements and norms at the international, regional and national levels (considered to be the macro-structure of governance), policy implementation and adjustment (meso-level of governance analysis) and the decision-making and management activities taking place within a specific locality associated with a given community, groups or individuals. See F Fischer and others (eds), Handbook of Public Policy Analysis. Theory, Politics and Methods (CRC Press Taylor \& Francis Group 2007). In terms of environmental management, this approach follows the moto 'think globally, act locally' introduced by the environmental movement of the 6os and 7os, while it also epitomizes significant parameters of the ecosystem based approach ( $\mathrm{n} 18$ ), since apart from the localization of (inter)national policies, the regulation of specific policy areas is conducted through the exercise of individual or community agency and the use of local knowledge. See M Aynul Islam, 'Microgovernance: A Prospective Tool of Good Governance in Bangladesh' (2007) 28 BIIss Journal 1. The debate on different micro-governance dimensions of maritime affairs is currently in progress, see Emilie Lindkvist and others, 'Micro level explanations for emergent patterns of self-governance arrangements in small-scale fisheries. A modelling approach' (2017) 12 PLOS 4: e0175532.

4 Apart from the adoption of a Directive on MSP in 2014, see European Parliament and Council Directive 2014/89/EU of 23 July 2014 establishing a framework for maritime spatial planning [2014] OJ L 257/135 (MSP Directive), the projects financed by the European Union constitute illustrative examples of this tendency: Plan Bothnia - Preparatory action on maritime spatial planning in the Baltic Sea (2010-12), BaltSeaPlan - Baltic Sea region programme 'Introducing Maritime Spatial Planning in the Baltic Sea' (2009-12), TPEA - Transboundary Planning in the European Atlantic - Project on maritime spatial planning in the Atlantic, including the Celtic Sea and Bay of Biscay (2012-14), ADRIPLAN - ADRiatic Ionian maritime spatial PLANning (2013-15), SIMCELT - promoting practical cross-border cooperation between EU countries on the implementation of the maritime spatial planning directive in the Celtic Seas (2015-17), Baltic SCOPE - Cross-border solutions in Baltic maritime spatial plans (2015-17), 
Public participation, or societal engagement, has been identified as a core principle of the ecosystem approach in ocean governance. This chapter examines the issue of public participation in the context of MSP drawing on the progress achieved at the international, EU and sub-regional levels (including EU basins, macro-regions and state practice) in order to assess the emerging discourse on the normative evolution of the principles of public participation in this domain and its impact on ocean governance.

\section{$2 \quad$ The Concept of Public Involvement and the Ecosystem Based Approach}

The interplay between societal interests and the state apparatus in given policy domains has long been discussed, especially in terms of citizens' participation in decision-making within a given society. Arnstein's 1969 analysis of the eight levels of participation in decision-making processes including manipulation, therapy, information, consultation, placation, partnership, delegated power, and citizen control is considered to be a classic contribution in this context. ${ }^{6}$ Since then, a shift of focus from citizens to interest groups, from democratic and social legitimacy to policy efficiency, and from the national sphere of politics to the international level, has taken place. Indeed, establishing the linkage between public planning and democratic decision-making in an era of highly specialized policies and the role of technocrats and experts was one of the main theoretical preoccupations in the domain of policy analysis during the 1980 s. $^{7}$ This shift was also mirrored in the inclusion of the concept

MARSPLAN - MSP in the Black Sea (2015-17), SIMNORAT - Atlantic Sea (2017-18), SIMWESTMED - Western Mediterranean (2017-18), SUPREME - Eastern Mediterranean (2017-18). See Commission, 'Funding MSP cross-border projects' <https://ec.europa.eu/maritimeaffairs/ policy/maritime_spatial_planning_en>accessed on 27 September 2017.

5 UN Environment Programme (Mediterranean Action Plan), 'Marine Spatial Planning and the protection of biodiversity beyond national jurisdiction (BBNJ) in the Mediterranean Sea' (17 February 2017) UNEP(DEPI)/MED WG.431/Inf.8. The European Commission in its vision for international ocean governance states its intention to promote MSP at a global level and work toward this end through the elaboration of a proposal 'for internationally accepted guidelines'. See Commission, 'International ocean governance: an agenda for the future of our oceans' JoIN (2016) 49 final, 13-14.

6 See SR Arnstein, 'A Ladder of Citizen Participation' (1969) 35 Journal of the American Planning Association 216 <http://lithgow-schmidt.dk/sherry-arnstein/ladder-of-citizen -participation.html\#doe70> accessed on 22 April 2017.

7 J DeSario and S Langton, 'Citizen Participation and Technocracy' (1984) 3 Public Policy Review 2, 223; M Grisez Kweit and RW Kewit, 'The Politics of Policy Analysis: The Role of Citizen Participation in Analytic Decisionmaking' (1984) 3 Public Policy Review 2, 234. More 
of public involvement or stakeholders' involvement in the domain of strategic management, ${ }^{8}$ as well as in the agenda of international institutions that implemented policy reforms. The World Bank, for example, developed a concrete methodology for stakeholder analysis to ensure the efficiency of its projects. ${ }^{9}$ In the decades that followed, research on the non-hierarchical coexistence of state and non-state actors in the formulation and effective implementation of decisions as well as in policy change, gained ground. More precisely, the idea of policy networks and the concept of hybrid governance were introduced into political science academic discourse.

The concept of policy networks, comprising the 'actors involved in the formulation and implementation of a policy' in a given policy domain, focused on the 'informal interactions between public and private actors with distinctive, but interdependent interests, who strive to solve problems of collective action on a central, non-hierarchical level'.10 Building on this approach, hybrid governance moved one step further and attempted to create a theoretical premise for the coexistence of formal and informal institutions and processes (the term 'informal' corresponds to non-governmental agents) where the latter take over functions that are traditionally performed by states. Hybrid governance schemes may result from states' failure to provide basic services and goods to their population. Nevertheless, they are also related to Western-type governmental structures and international institutions. In Western liberal democracies, the intermingling of formal and informal processes is institutionalized, and the existence of non-governmental agents is not dependent on the lack of efficiency of the state apparatus. Regional and international institutions also follow this practice. Although traditionally restricted to interstate cooperation, a model that still persists in contemporary international relations, the pursuit of supranational structures of governance in certain policy domains (especially at the regional level), the need for social legitimization (as in the case of the consultation processes in the European Union political environment), the demand for expertise (in domains such as environmental protection and

specialized dimensions of this issue have gained ground in the more recent academic debate, e.g. the role of the epistemic community in EU decision-making, see M Lee, 'The Legal Institutionalization of public participation in the EU governance of technology' (June 2014) ECPR Regulatory Governance Conference <https://papers.ssrn.com/sol3/ papers.cfm?abstract_id=2461145 $>$ accessed on 2 October 2018.

8 R Edward Freeman, Strategic Management: A Stakeholder Approach (1984, reprinted by Cambridge University Press 2010).

9 World Bank, 'Stakeholder Analysis', <http://www1.worldbank.org/publicsector/anti corrupt/PoliticalEconomy/stakeholderanalysis.htm > accessed on 6 November 2016.

10 See TA Börzel, 'Organizing Babylon - On the different conceptions of policy networks' (1998) 76 Public Administration 253, 260. 
climate change), and the need to outsource certain functions due to lack of human and financial resources, have enhanced the role of informal agents in the decision-making processes as well as in the implementation of international policies. ${ }^{11}$

Despite these developments, stakeholder involvement in governance and its linkage to good (ocean) governance as a fundamental element of sustainable development ${ }^{12}$ has been systematically promoted in the domain of environmental protection, an issue area that transcends the limits of national decision-making processes. ${ }^{13}$ Initially introduced as a principle of environmental management in international declarations and action plans, ${ }^{14}$ public participation was soon incorporated into international treaties such as the 1992 Convention on Biological Diversity, ${ }^{15}$ regional instruments such as the 1998 Aarhus Convention, ${ }^{16}$ as well as in EU environmental legislation. ${ }^{17}$ These texts constitute illustrative examples of the adoption of legally binding commitments on behalf of their contracting parties or of the EU member states

11 See V Boege and others, 'On Hybrid Political Orders and Emerging States: State Formation in the Context of 'Fragility' (October 2008) Berghof Research Center for Constructive Conflict Management, <http://edoc.vifapol.de/opus/volltexte/2011/2595/pdf/boege_etal_ handbook.pdf> accessed on 31 May 2017; L Sauvée, 'Hybrid governance: sketching discrete alternatives' (2013) 13 Journal on Chain and Network Science 1. See also, TA Brozel and T Risse, 'Dysfunctional State Institutions, Trust and Governance in Areas of Limited Statehood' (2016) 10 Regulation \& Governance 149.

12 Y-C Chang, Ocean Governance (Springer Briefs in Geography 2012) 32.

13 See N Perkins Spyke, 'Public Participation in Environmental Decisionmaking at the New Millennium: Structuring New Spheres of Public Influence' (1999) 26 Boston College Environmental Affairs Law Review 263. For a literature review in stakeholder participation in the environmental protection regime, see MS Reed, 'Stakeholder Participation for Environmental Management: A Literature Review' (2008) 141 Biological Conservation 2417 and National Research Council, Public Participation in Environmental Assessment and Decision Making (The National Academies Press 2008).

14 From the 1992 Rio Declaration on Environment and Development to the recent adoption of the Sustainable Development Goals in 2015. See General Assembly, 'Report on the United Nations Conference on Environment and Development' [1992] A/CONF.151/26 (Vol. I), Annex I - Rio Declaration on Environment and Development and General Assembly, 'Transforming our world: the 2030 Agenda for Sustainable Development' UNGA Res 70/1 (25 September 2015) UN Doc. A/REs/70/1.

15 Convention on Biological Diversity [1992] 176o UNTS 79.

16 Convention on Access to Information, Public Participation in Decision-Making and Access to Justice in Environmental Matters (Aarhus Convention) [1998] 2161 UnTS 447.

17 E.g. European Parliament and Council Directive (EC) 2003/35/EC providing for public participation in respect of the drawing up of certain plans and programmes relating to the environment [2003] OJ L 156/17. 
concerning certain dimensions of public participation in environmental decision-making.

The crystallization of the ecosystem approach has widened the spectrum of pure environmental management principles. Although it lacks a '... universally agreed definition,', 18 there is general agreement that implementation of the ecosystem approach should, inter alia, be 'inclusive' in terms of 'stakeholder and local communities' participation in planning, implementation and management' and in balancing diverse societal objectives with environmental protection. ${ }^{19}$ In this way, the ecosystem approach combines conservation and sustainable development with social equitability.

In this context, public participation can be broadly defined as the '[involvement of] members of the public in the agenda-setting, decision-making and policy-forming activities of organizations/institutions responsible for policy development. ${ }^{20}$ It encompasses various types of public involvement, namely: (a) public communication in which competent authorities inform the public about their intentions although the public is not expected to provide any feedback to the sponsors of the proposed policy; (b) public consultation in which the public is invited by the sponsors of the proposed policy to express its opinion which is conveyed to the competent authorities; and, (c) public participation in which an official dialogue between the sponsors of the new policy and the public is conveyed, the objectives and the working methods towards their achievement are negotiated and there is a degree of 'formal' stakeholder participation in decision-making. ${ }^{21}$

In terms of the different phases of public participation these can be classified based on temporal criteria, namely: ex ante public engagement; involvement in the consultation process; and ex post participation. ${ }^{22}$ Ex ante public engagement takes place before the actual policy formulation phase, usually following competent authorities' initiatives. However, political parties, most often not those in power, as well as academic or thematic advocacy groups such as those espousing environmental or economic concerns, may also trigger public engagement processes. At this stage, the focus is mainly on

18 United Nations, 'Report on the Work of the United Nations Open-Ended Informal Consultative Process on Oceans and the Law of the Sea at its Seventh Meeting' (July 2006) A/61/156 17, 2 par. 6 .

19 Ibid.

20 G Rowe and L Frewer, 'A Typology of Public Engagement Mechanisms' (2005) 30 Science, Technology \& Human Values 251, 253.

21 Ibid., 254-256.

22 P André and others, 'Public Participation. Best Practice Principles' (August 2006) IAIA Special Publication Series 4. 
information - sensitization activities. Involvement in consultation processes refers to involvement in actual decision-making, and depends on the institutional framework and the political culture ${ }^{23}$ of a given constituency. Finally, ex post participation refers to participation in the assessment process and contribution to adaptive management processes, which is a crucial component of the ecosystem-based approach.

Departing from the discussion on the theoretical and normative dimensions of public participation within the framework of the ecosystem approach, its practical dimensions in MSP ventures will be examined. Before moving to the examination of the practice of different actors involved in MSP processes, however, the role of MSP within the broader context of ocean governance as well as the institutional landscape for MSP public participation will be analyzed.

\section{MSP: A New Philosophy in Ocean Governance?}

MSP is a relatively new practice introduced initially to meet the needs of marine environmental protection at the national level as, for example, in the case of the Great Barrier Reef in Australia. ${ }^{24}$ During the 1990 and 2000 s the use of MSP proliferated around the globe. ${ }^{25}$ At the same time, a gradual shift occurred from conducting MSP strictly for environmental management to a more comprehensive perception of the spatial allocation of human activities and natural processes in the marine space. The adoption of the first transboundary MSP venture, the Trilateral Wadden Sea Plan, ${ }^{26}$ revealed the growing significance of MSP for comprehensive management of marine space both in terms of the different sectoral policies and spatially, particularly in relation

23 Almond and Verba have defined political culture 'as the particular distribution of patterns of orientation toward political objects among the members of the nation'. GA Almond and S Verba, The Civic Culture. Political Attitudes and Democracy in Five Nations (Sage 1963), 13. The authors have also introduced a typology of orientations, '(1) cognitive orientation, that is knowledge of and belief of the political system, its roles and the incumbents of these roles, its inputs, and its outputs; (2) affective orientation, or feelings about the political system, its roles, personnel, and performance, and (3) evaluational orientation, the judgments and opinions about political objects that typically involve the combination of value standards and criteria with information and feelings', ibid., 14.

24 Jon Day, 'The need and practice of Monitoring, Evaluating and Adapting Marine Planning and Management - Lessons from the Great Barrier Reef' (2008) $3^{2}$ Mar Policy 823.

25 S Jay and others (n 2).

26 Adopted by Germany, the Netherlands and Denmark for the protection of the Wadden Sea (n 94). 
to the coordination of national policies and uses in a marine area falling within the jurisdiction of different states.

Despite this progress, however, MSP implementation lacked a common conceptual and normative framework, since it consisted of tailor-made initiatives developed in specific spatial and institutional contexts. UNESCO was the first organization to address these issues systematically. In 2006 it organized the first international workshop on MSP. The outcomes of the workshop included a Guide for $\mathrm{MSP},{ }^{27}$ a technical report, ${ }^{28}$ as well as a special issue of the international journal, Marine Policy with contributions discussing the different dimensions of MSP, which appeared in September 2008. ${ }^{29}$ According to UNESCo's workshop outcomes, MSP was defined as 'a [public] ${ }^{30}$ process of analyzing and allocating parts of three-dimensional marine spaces to specific uses, to achieve ecological, economic and social objectives that are usually specified through the political process; the MSP process usually results in a comprehensive plan or vision for a marine region. MSP is an element of [ecosystem-based $]^{31}$ sea use management. ${ }^{32}$

Shortly thereafter, the European Union (EU) provided general guidance on the meaning and application of MSP. In its Roadmap for MSP, published in 2008, the European Commission defined MSP as 'a tool for improved decisionmaking' that would function as 'a framework for arbitrating between competing human activities and managing their impact on the marine environment' with the 'objective (...) to balance sectoral interests and achieve sustainable use of marine resources' ${ }^{33}$ While in the 2008 Roadmap environmental primacy is still preserved, two conceptual elements prevail: first, MSP is presented as purely managerial in character since it is perceived as a governance tool to be used in order to support existing sectoral policies, and not a process as defined

27 C Ehler and F Douvere, Marine Spatial Planning: A step-by-step approach toward ecosystem-based management, Intergovernmental Oceanographic Commission (IOC) and Man and the Biosphere Programme, Ioc Manual and Guides 53, ICAM Dossier, 6 (UNESCO 2009).

28 C Ehler and F Douvere, Visions for a Sea Change. Report of the First International Workshop on Marine Spatial Planning. Intergovernmental Oceanographic Commission and Man and the Biosphere Programme, Ioc Manual and Guides 46, ICAm Dossier, 3 (Unesco 2007).

$29<\mathrm{http} / /$ www.sciencedirect.com/science/journal/0308597X/32/5?sdc=1> accessed on 17 May 2017.

30 C Ehler and F Douvere (n 27), 18.

31 Ibid., 7, 10.

32 C Ehler and F Douvere (n 28), 13.

33 Commission, 'Roadmap for Maritime Spatial Planning: Achieving Common Principles in the EU' сом (2008) 791 final, 2. 
by UNESCO; second, the MSP concept transcends its environmental functional character by being associated with the 'competitiveness of the EU's maritime economy'. It is perceived as a 'framework providing legal certainty and predictability' and promoting 'investment in such sectors, which include offshore energy development, shipping and maritime transport, ports development, oil and gas exploitation and aquaculture, boosting Europe's capacity to attract foreign investment. ${ }^{34}$

In 2014 the EU adopted the MSP Directive, which provided a broader definition of MSP in line with that adopted within the framework of UNESCO's 2006 initiative. According to the Directive, MSP is a 'process by which the relevant member state's authorities analyze and organize human activities in marine areas to achieve ecological, economic and social objectives. ${ }^{35}$ The Directive's provisions are related to the obligations of member states and their position vis à vis the international ocean governance system. MSP is perceived as 'the logical advancement and structuring of obligations and of the use of rights granted under UNCLOS and a practical tool in assisting member states to comply with their obligations'. ${ }^{36}$ In this context, member states are obliged to prepare spatial plans according to their national priorities and institutional mechanisms. The role of regional institutions' acquis and structures are also mentioned in the Directive's text as the most suitable mechanisms for the cooperation among neighbouring member states and, wherever possible with third countries, taking into account the ecological unity of marine space.

In 2017, a second international workshop was organized by UNESCO jointly with the European Commission (EC). ${ }^{37}$ The objectives of the workshop included the dissemination and consolidation of MSP good practices worldwide, and the linkage of MSP to global ocean governance challenges, including the implementation of Sustainable Development Goals within the framework of the UN 2030 Agenda, ${ }^{38}$ climate change mitigation and adaptation, and management of areas beyond national jurisdiction. ${ }^{39}$ This initiative reflects efforts aimed at promoting inter-institutional coordination, on the one hand, and

$34 \quad$ Ibid. at 3.

35 MSP Directive (n 4), article 3 para 2.

36 Ibid., preambular para 7 .

37 Unesco, '2nd International Conference on Marine Spatial Planning' <https://en.unesco.org/events/2nd-international-conference-marine-spatial-planning $>$ accessed on 10 December 2017.

38 General Assembly, 'Transforming our World: The 2030 Agenda for Sustainable Development' (n 14).

39 Intergovernmental Oceanographic Commission, European Commission - DG MARE, The 2nd International Conference on Marine/Maritime Spatial Planning, 15-17 March 2017, IOC Workshop Series 279 (UNESCO 2017). 
the mainstreaming or incorporation into the MSP agenda of new challenges related to ocean governance, on the other.

The main conclusion to be drawn from this short discussion of the evolution of MSP, whether at the national level or regionally, is that its basic conceptual premises are consistent with international law allocating states' rights and obligations at sea. ${ }^{40}$ In this context, MSP is founded on the comprehensive approach of UNCLOS towards the 'problems of the ocean space' which 'are closely interrelated and need to be considered as a whole', and on its provisions for 'bilateral, regional and international cooperation'. However, MSP processes seem to 'modernize' the traditional governance logic of UNCLOS which is filtered through the lens of the ecosystem approach, by integrating environmental with concrete economic and societal objectives on the one hand and promoting transboundary cooperation under common management plans on the other. In practice this is depicted in the gradual abandonment of the zoning practice in MSP (which is common in environmental management for example) in favor of the establishment of 'multiple use' marine areas. ${ }^{41}$

Additionally, MSP constitutes one of the few, if not the only, governance tools, whose effective conduct, due to its multifunctional and multilevel character and the different interests it attempts to balance, depends on the degree of public trust in MSP ventures. ${ }^{42}$ The development of societal confidence in MSP is linked to public participation in relevant decision-making processes. ${ }^{43}$ The type of public involvement, as well as the degree of institutionalisation of the relevant MSP processes are determined mainly by the constitutional framework and administrative system of different countries. However, as will be seen below, public engagement in MSP is a complex process, particularly considering the proliferation of relevant projects at the national level, the lack of MSP regulation at the international level and the evolution of spatial planning on an ad hoc basis in different regional marine areas.

40 For a comprehensive analysis of the international legal regime on maritime spatial planning see Frank Maes, 'The International Legal Framework for Marine Spatial Planning' (2008) 32 Mar Policy 797, M RAG, 'Legal Aspects of Maritime Spatial Planning', Final Report to DG Maritime Affairs and Fisheries, Framework Service Contract, No. FISH/2006/ogLOT-2, October 2008 and HELCOM, 'Joint HELCOM-VASAB Maritime Spatial Planning Working Group Report 2010-2013' (2013).

41 S Jay and others (n 2), Sarah Carr, 'What Role does Ocean Zoning Play in Marine Spatial Planning? Viewpoints from the EU, US and China' (2011) <https://meam.openchannels .org/news/meam/what-role-does-ocean-zoning-play-marine-spatial-planning -viewpoints-eu-us-and-china> accessed on 22 February 2018.

42 C Ehler and F Douvere (n 27), 40.

43 Ibid. 


\section{Public Engagement in MSP: The Emerging International Institutional Landscape}

The evolution and the institutionalization of MSP practice discussed above have brought to the fore a broad consensus concerning public participation as a sine qua non for successful MSP projects. This is reflected in the progressive incorporation of participation provisions into soft law documents and other instruments adopted by international organizations and in the recently adopted MsP legislation at the EU level.

\subsection{From Soft Law ...}

Public trust, as mentioned above, is recognized as the basis for successful MSP by every international, regional or sub-regional institution or initiative involved in such processes. Within these contexts, during the last decades we have witnessed the elaboration of standards, criteria and guidelines addressing the different dimensions of public participation as a means for ensuring the viability of MSP projects in an attempt to address the following issues: who will be involved (related to stakeholders' mapping); when (during the preparation, the decision-making, the assessment phases); in what form (at the (sub) national or regional levels); and in what degree (participation will be restricted to information of the public or the participation of the latter in actual decision-making shall be ensured)? ${ }^{44}$

Stakeholder mapping, or the identification of 'groups, individuals, organizations [and institutions], involved or affected, positively or negatively', ${ }^{45}$ by M SP, constitutes one of the most significant challenges in this process since representation gaps may undermine social legitimization, create frictions among societal partners and mistrust vis à vis the competent authorities. ${ }^{46} \mathrm{Broad}$ participation of key stakeholders is considered significant in MSP decisionmaking since it contributes to wider 'acceptance, ownership and support'47 for MSP ventures and to confidence building among competent authorities

\footnotetext{
44 Ibid., 46-48.

45 The definition of R Pomeroy and R Rivera-Guieb, Fishery co-management. A practical handbook (CABI Publishing and International Development Research Centre 2006), mentioned by R Pomeroy and F Douvere, "The Engagement of Stakeholders in the Marine Spatial Planning Process' (2008) 32 Marine Policy 816, 818.

46 Intergovernmental Oceanographic Commission, European Commission - DG MARE (n 39), 20.

47 Commission, 'Roadmap for Maritime Spatial Planning: Achieving Common Principles in the EU' (n 33), 9 .
} 
and stakeholders. 'Broad' may refer to stakeholders that represent different interests, ${ }^{48}$ or that originate from different countries. ${ }^{49}$ However, broad does not mean without a focus. The relationship of stakeholders to the MSP project in question remains the first criterion to be met for their involvement in the relevant consultation processes.

According to the guidelines produced by the 2006 UNESCO workshop on MSP, several parameters are to be taken into account in defining the correct target groups. ${ }^{50}$ The relationship of stakeholders to the resources (economic, social or cultural) of the specific marine area is prioritized. Another parameter to be considered is the continuity of this relationship (whether it is linked to permanent or temporal activities) as well as the gains or losses of different interest groups that accompany the change or the multiplication of uses of the marine space envisaged in MSP. Stakeholders may also be assessed in terms of their capabilities to support management processes in line with the ecosystem based approach, including the provision of scientific and/or traditional knowledge that 'can significantly raise the quality of MSP'.51 Last, but not least, the credibility of stakeholders in relation to their motives to be involved in public participation processes should also be taken into account through the examination of the consistency of their activity vis à vis their interests. ${ }^{52}$

Considering the above-mentioned criteria, the safest categorization of MSP stakeholders encompasses public institutions (other than the competent authorities for MSP and relevant authorities from neighboring states), the environmental advocacy community (including both academia and activists), the ocean users community (shipping, fishermen, the tourist industry, offshore energy industry, and so on), local communities (groups with historical and cultural ties with tangible and intangible elements of the marine space), political parties (especially via Members of Parliament that have strong ties with their constituency) and individuals (ranging from experts to individual participation in communication or consultation processes). ${ }^{53}$

48 Ibid.

49 Baltic Marine Environment Protection Commission, 'Guidelines on transboundary consultations, public participation and co-operation, Laulasmaa, Estonia, 15-16 June 2016', HOD 50-2016.

5o C Ehler and F Douvere (n 27), 44 (box 17).

$5^{1}$ Commission, 'Roadmap for Maritime Spatial Planning: Achieving Common Principles in the EU' (n 33), 9.

$5^{2}$ C Ehler and F Douvere (n 27), 44 (box 17).

53 See Intergovernmental Oceanographic Commission, European Commission - DG MARE (n 39). 
Once key stakeholders are identified, competent authorities should deal with the timing of their involvement. Sustained participation, that is involvement in all stages of the MSP venture, information/communication activities, as well as decision-making processes concerning planning, implementation and monitoring of MSP, is considered a good practice. ${ }^{54}$ In this context, early engagement of stakeholders is significant not only at the national level but also through the establishment of formal processes of transboundary information exchange and consultation as the basis for policy coordination and the avoidance of friction among neighboring countries. .55

Moving to the issue of the extent of public involvement, the first condition to be fulfilled to create and sustain societal confidence in spatial planning is that of transparency. This requires that official decisions regarding MSP should be open to public scrutiny. Information activities involving the general public constitute the basis for the development of public trust. Thus, once wide transparency is ensured, and the key stakeholders are identified, competent authorities must decide on the actual role of stakeholders in MSP decision making. The factors that determine variations in the degree of public participation are not always of an institutional nature. According to Douvere ' $[t]$ he scope and extent of stakeholder involvement differs greatly from country to country' since it 'largely depend[s] on the political or legal requirements for participation that already exist in a particular country (...) and is often culturally influenced., 56

Standard-setting processes in this domain are still being developed as MSP implementation is pursued around the globe. ${ }^{57}$ However, as discussed below, certain of these general principles of normative value have been incorporated in the EU MSP Directive.

54 C Ehler and F Douvere (n 27), 43-48. The principles on participation set out in the White Paper on European Governance call for 'ensuring wide participation throughout the policy chain - from conception to implementation', Commission, 'European Governance: A White Paper' сом (2001) 428, 8.

55 As mentioned in Intergovernmental Oceanographic Commission, European Commission - DG MARE (n 39), the VASAB-HELCOM Guidelines (n 40) and the 2010 European Commission Communication, Commission, 'Maritime Spatial Planning in the EU Achievements and Future Development' сом (2010) 771.

$5^{6} \quad$ F Douvere, Marine spatial planning: Concepts, current practice and linkages to other management approaches (Ghent University Belgium 2010), 65 <https://biblio.ugent.be/ publication/8509486/file/8509487.pdf > accessed on 18 May 2017.

57 Intergovernmental Oceanographic Commission, European Commission - DG MARE (n 39). 


\section{2 ... to Regulation at the Regional Level}

In the regional context, in 2014, the EU MSP Directive became the first legally binding act at the regional level, ${ }^{58}$ providing for public participation in MSP decision making processes. According to article 9 of the Directive 'member states shall establish means of public participation by informing all interested parties and by consulting the relevant stakeholders and authorities, and the public concerned, at an early stage in the development of maritime spatial plans, in accordance with relevant provisions established in Union legislation. Member states shall also ensure that the relevant stakeholders and authorities, and the public concerned, have access to the plans once they are finalized'.

Public participation is conceived in modest terms since article 9 only provides for informative and consultative processes, leaving to the discretion of states the option of a more enhanced public involvement. The same goes for the obligation on the competent authorities to provide access to relevant stakeholders, authorities and the public concerned, which is limited to access to the plans 'once they are finalized' and not at an earlier stage of elaboration.

Additionally, the Directive stipulates that member states bordering marine waters are obliged to cooperate (article 11) while, in the case of member states bordering third states, there is a more tempered reference to cooperation since member states 'shall endeavour, where possible, to cooperate with third countries' (article 12). Although not explicitly stated or defined in terms of process, public involvement is implied in these articles, especially if one considers that the reference in article 9 to 'interested parties', 'relevant stakeholders and authorities' and the 'public concerned' is not restricted to the national level.

Despite the ample space left for the competent authorities of member states to decide on the means and the degree of public involvement, reference to 'relevant provisions established in Union legislation', should also not be ignored. The relevant legislative framework comprises, inter alia, the implementation of the provisions of the Aarhus Convention through Regulation 1367/2006,59 Directive 2003/35 concerning the drawing up of certain plans and programs

$5^{8}$ For a discussion on the evolution of the legalization process of the EU in the domain of MSP, see A Zervaki, 'The Legalization of Maritime Spatial Planning in the European Union and its Implications for Maritime Governance' (2016) 30 Ocean Yearbook 32.

European Parliament and Council Regulation (EC) 1367/2006 of 6 September 2006 on the application of the provisions of the Aarhus Convention on Access to Information, Public Participation in Decision-making and Access to Justice in Environmental Matters to Community institutions and bodies [2006] OJ L 264/13. 
relating to the environment, ${ }^{60}$ as well as Directive $2003 / 4$ on public access to environmental information. ${ }^{61}$

EU legislation concerning environmental assessment is also relevant; competent authorities' marine plans should comply with the provisions of the Strategic Environmental Assessment Directive ${ }^{62}$ concerning consultations with relevant authorities and the public (Article 6), ${ }^{63}$ transboundary consultations (Article 7) and information on the adopted plan (Article 9) among EU member states, ${ }^{64}$ when the conditions set by the Directive are met. The provisions of the Environmental Impact Assessment Directive concerning public participation should also be considered at a later stage of the MSP Directive's implementation in relation to the realization of the specialized components of the spatial plans. According to Article 7, consultation among member states is foreseen where a project is likely to have significant effects in another member state. The procedure encompasses all stages of public involvement, from public communication involving the provision of information to the competent authorities of the member state to be affected as well as the general public on its territory, to public consultation aimed at ensuring that the authorities and the public of the member state to be affected are given an opportunity to forward their opinion to the competent authority of the member statesponsor, and to public participation in decision making through the initiation of consultations among member states, which may be conducted 'through an appropriate joint body'.65

60 Directive 2003/35/EC (n 17).

61 European Parliament and Council Directive (EC) 2003/4 of 28 January 2003 on public access to environmental information and repealing Council Directive 9o/313/EEC [2003] OJ L $41 / 26$.

62 European Parliament and Council Directive (EC) 2001/42 of 27 June 2001 on the assessment of the effects of certain plans and programmes on the environment [2001] OJ L 197/30 (SEA Directive).

63 In Portugal for example, during the preparation phase of the Plano de Ordenamento do Espaço Marítimo (POEM), a public consultation was organized between 29 November 2010 and 22 February 2011, implementing the relevant provisions of Decree-Law No. 232/2007 (amended by Decree-Law No. 58/2011), that transposed Directive 2001/42/ EC. European MSP Platform, 'Maritime Spatial Planning Country Information, Portugal (November 2017)' <https://www.msp-platform.eu/sites/default/files/download/portugal _02.11.2017.pdf> accessed 25 September 2018.

64 As in the case of German MSP in the North Sea and in the Baltic Sea (n 92 and n 93).

65 European Parliament and Council Directive (EU) 2014/52/EU of 16 April 2014 amending Directive 2011/92/EU on the assessment of the effects of certain public and private projects on the environment [2014] OJ L 124/1. 
Following the presentation of the evolving MSP patterns and norms at the international and the European level, this section discusses the actual practice of MSP public participation, focusing on the experience of EU member states and MSP cooperation among national authorities and/or stakeholders at the sub-regional level. The focus on the EU is intentional since its member states participate in or constitute the recipients of both international and EU standard setting processes in this domain.

\subsection{Stakeholders' Mapping and Participation: Identity, Roles and Objectives}

Consistent with the ecosystem approach, MSP should be founded on best available data and knowledge. The MsP Directive also mentions that '(...) it is essential that member states make use of the best available data and information by encouraging the relevant stakeholders to share information' ${ }^{66}$ Thus, the scientific community is an important partner in the design and implementation of MSP. However, cooperation between scientists and policymakers is not easy since they do not share a common working methodology or objectives. Considering this relationship from the experience of environmental protection, the objective character of scientific research may often contradict the political orientations of policy decisions that are shaped by a plurality of factors such as societal expectations or economic interests. ${ }^{67}$ In MSP these differences may be further accentuated due to the integration of different policies in a single project. In EU member states the degree of participation of the scientific community depends on the legal personality of the institution concerned and its linkage to governmental authorities (if it constitutes a governmental agency or not), or on the powers vested in different epistemic institutions by the competent MSP authorities. In the case of Germany, the Federal Maritime and Hydrographic Agency ( $\mathrm{BSH}$ ), an agency under the supervision of the Federal Ministry of Transport, Building and Urban Affairs, is in charge of MSP for the German exclusive economic zones in the North Sea and the Baltic Sea. ${ }^{68}$ In Greece, the Hellenic Centre for Marine Research as well as relevant

66 '(...) and by making use of existing instruments and tools for data collection, such as those developed in the context of the Marine Knowledge 2020 initiative and Directive 2007/2/ EC of the European Parliament and of the Council' (preambular para 24).

67 See S Fletcher, 'Converting science to policy through stakeholders' involvement: an analysis of the European Marine Strategy Directive' (2007) 54 Marine Pollution Bulletin 1881.

68 Federal Maritime and Hydrographic Agency, 'Federal Government's provider of maritime services' <http://www.deutsche-flagge.de/en/german-flag/flag-state/bsh-federal -martime-and-hydrographic-agency-1> accessed on 25 September 2018. 
university departments, which are public institutions but not governmental agents, have been only partially involved in providing the necessary data as well as participating in the public debate on the priorities for MSP in Greece. 69

Public participation also involves ocean advocacy groups and ocean users. The contribution of NGOS, for example, ranges from provision of expertise, conduct of field work, and participation in monitoring and assessment activities, to public participation facilitation through the conduct of campaigns or even undertaking a more activist stance through demonstrations (e.g. in cases environmental degradation is considered to be linked with the change in uses of marine space etc.). ${ }^{70}$ The approach of NGOs, especially in the domain of environmental or human rights protection, is mainly guided by the public goods approach ${ }^{71}$ and focuses on the promotion of both monetized and nonmonetized values and benefits in MSP projects. ${ }^{72}$

Professional associations on the other hand, advocate the interests of the individuals engaged in the respective professions. The consent of these associations is significant to MSP design and implementation since they have a significant political leverage in governmental decision-making processes and policy implementation, and they also contribute to MSP assessment activities. The added value of these associations is that they may also have a positive impact on MSP (once their support is granted) through the evolution of professional attitudes and perceptions towards the uses of the marine space. ${ }^{73}$

69 Mainly through participation in EU projects such as ADRIPLAN $(n)$ or the collaboration of Greece and Cyprus under the INTERREG programme involving the development of common MSP methodology and pilot projects to be implemented in the two countries. See Cross-border Cooperation Programme 'Greece - Cyprus 2007-2013' <http://www .mspcygr.info/> accessed 17 September 2017. See also V Vassilopoulou and others, Declaration on the Development of Maritime Spatial Planning in Greece, adopted within the framework of the nth Panhellenic Symposium on Oceanography and Fisheries, organized by the Hellenic Centre for Marine Research and the University of the Aegean, Lesvos, May 2015, <http://www.symposia.gr/wp-content/uploads/2015/o6/MSP_declaration_web.pdf> accessed on 2 September 2017.

70 For the multidimensional role of NGOs in MSP, see H Calado and others, 'NGO involvement in marine spatial planning: a way forward?' (2012) 36 Marine Policy 382.

71 Considering the environment as a non-excludable and non-rivalrous good, most environmental NGOs perceive the marine space 'as part of the public domain, not owned exclusively or to be benefited by any one group or private interest'. Ehler and Douvere (n 27) 40.

72 See Anne D Guerry and others, 'Modeling benefits from nature: using ecosystem services to inform coastal and marine spatial planning' (2012) 8 International Journal of Biodiversity Science, Ecosystem Services \& Management 1-2, 107.

73 The role of fisheries professionals in decision-making processes is significant. See S Mackinson and others, 'Engaging stakeholders in fisheries and marine research' (2011) 35 Marine Policy 18. 
Last, but not least, the market sector, comprised mainly of companies, ${ }^{74}$ represents private interests translated into monetary value and their principal aim is to safeguard their existing and potential economic prospects in MSP.

All the above-mentioned entities participate in the different phases of MSP via formal and informal channels (by lobbying or through the exertion of political pressure, e.g. in the domain of investments). In the case of formal public participation, the establishment in France in 2009 of the Grenelle de la Mer bringing together government representatives, politicians, scientists, unions and NGOs in order to define a common framework to integrate maritime and coastal activities, was, at the time of its launching, one of the most advanced examples of public participation in maritime policy formulation. ${ }^{75}$ In other countries MSP has been incorporated into the agenda of consultative bodies with a broader vision, as in the case of the Federal Council for Sustainable Development ${ }^{76}$ in Belgium; an advisory body, with the participation of representatives of environmental organizations, the development sector, employers and employees in the maritime sector and academia. In other cases, advisory bodies on terrestrial spatial planning have extended their activity to include MSP, as in the case of the National Spatial Planning Council ${ }^{77}$ in Greece, the main consultation body for spatial planning, which includes the participation of scientists, environmental NGOs, regional authorities and professional associations. Such bodies can only influence, but not participate in, actual decision-making; however, their role is important since interested parties are not only informed, but their opinion is conveyed to the competent authorities, a process which usually triggers public debate, particularly in the regions concerned.

MSP public participation processes are also open to individuals, but only in the two first stages: communication and consultation. In Latvia for example, development of the national MSP included the involvement of individuals who had an interest in the decision-making or were affected by it. Individuals received information on the MSP authorities' intentions via the same channels

74 The shipping industry constitutes an illustrative example in this case. See D Patraiko and P Holthus, The Shipping Industry and Marine Spatial Planning. A Professional Approach (The Nautical Institute/World Ocean Council 2013).

75 République Française-Ministère de l'Écologie, de l'Energie, du Développement durable et de la Mer, 'Grenelle de la mer: vers un renouveau de la politique maritime?' < http://www .vie-publique.fr/actualite/dossier/grenelle-mer/grenelle-mer-vers-renouveau-politique -maritime.html> accessed on 15 June 2017.

76 Federal Council for Sustainable Development $<$ http://www.frdo-cfdd.be/en $>$ accessed on 18 September 2017.

77 Established under 'Special Planning. Sustainable Development and other provisions', Law 4447 [2016] A/241 <http://www.elinyae.gr/el/lib_file_upload/241A_2016.1484831674306 .pdf $>$ accessed on 20 September 2017. 
as other stakeholders (press, media, etc) and were able to participate in public hearings and written comments. ${ }^{78}$ In Greece, during the consultation for the transposition of the MSP Directive in 2016, individuals submitted their comments via the platform managed by the Ministry of Environment. Individual participation was considered high, given that 68 out of a total of 92 comments were submitted by individuals. ${ }^{79}$ In some cases, a special invitation is extended to individual experts, as in the case of the Grenelle de la Mer in France or the Greek National Spatial Planning Council where experts are appointed by the Minister of the Environment. ${ }^{80}$

\subsection{Levels of Public Participation in the EU}

5.2.1 Public Participation at the National Level

MSP competent authorities are usually the sponsors of public participation processes. However, due to the multifunctional character of MSP, before they proceed to the official launching of such processes they usually resort to 'firstlevel' consultations with other ministries and/or administrative divisions at the national level. In most cases these consultations are realized within interministerial committees. Membership in these bodies varies depending on the distribution of competences related to the maritime space, as well as national (MSP or other) priorities.

In Portugal, for example, the Plano de Ordenamento do Espaço Marítimo (POEM) was designed by the inter-ministerial committee for maritime affairs ${ }^{81}$ along with representatives from the autonomous regions of Madeira and Azores, ${ }^{82}$ while in Cyprus, the MSP ministerial committee comprises of representatives from the Ministries of Transport, Communications and Works,

78 Kristīna Veidemane, 'Stakeholder involvement in development of the Maritime Spatial Plan of Latvian waters' (2015), <https://www.bonusportal.org/files/4063/Kristina Veidemane_Baltic_Environmental_Forum_Latvia.pdf > accessed on 18 December 2017.

79 Ministry of Environment and Energy, 'Consultation site' <http://www.opengov.gr/ minenv/?p=8366> accessed on 18 December 2017 .

8o See Ministry of Environment and Climate Change, 'Establishment of the National Council on Spatial Planning and Sustainable Development', Ministerial Decree of 2nd July 2010, <http://www.ypeka.gr/LinkClick.aspx?fileticket=QDw\%2B2kQwQUI\%3D\&tabid=508> accessed 19 September 2017.

81 For the establishment of the Portuguese inter-ministerial committee for maritime affairs see Portuguese Republic, 'National Ocean Strategy' (2007), <http://www.ioc-unesco .org/images/stories/LawoftheSea/Documents/NationalOceanPolicy/nop.portugal.pdf> accessed on 2 October 2018.

82 With the support from the Portuguese Water Institute, external consultants, the Institute for Nature Conservation and Biodiversity, the Structure on the Mission for Maritime Affairs, the Portuguese Environmental Agency and the Structure on the Mission for the Extension of the Continental Shelf, as mentioned in H Calado and others, 'Marine Spatial Planning: Lessons Learned from the Portuguese Debate (2010) 34 Marine Policy 1341, 1346. 
Foreign Affairs and Defense, ${ }^{83}$ reflecting not only the functional but also the political character of the decisions to be taken in this domain (considering the occupation of the northern part of the country by Turkey). In these countries, the competent authority, usually a ministry, presides over meetings.

France has opted for centrally located inter-ministerial structures on maritime affairs, an inter-ministerial committee and a Secrétariat Général de la Mer, both under the Prime Minister. ${ }^{84}$ In Belgium, where MSP competences are shared between the central government and the Flemish authorities, the practice of consultations among ministries as well as respective administrations was popular during the first attempts to conduct M SP. ${ }^{85}$ In 2012, however, this process was formalized by the establishment of an advisory committee on MSP composed of representatives from all federal authorities with maritime competence and in which the Flemish authorities were also granted consultative status. ${ }^{86}$ In Greece, an inter-ministerial committee on maritime policy with broad participation from other ministries and with the possibility of inviting members of public and private bodies was created under the Ministry of Mercantile Marine and Island Policy in 2013. ${ }^{87}$ However, it has never been convened to discuss the prospects of MSP in Greece, since MSP competence passed to the Ministry of Environment and Energy (following the adoption of

83 Republic of Cyprus, 'Strategy for a National Integrated Maritime Policy', <http://www .cpa.gov.cy/CPA/userfiles/documents/strategy.pdf> accessed on 18 May 2017. In Cyprus a ministerial committee on MSP, with the participation of the Ministries of Transport, Communications and Works, Foreign Affairs and Defense, is also foreseen in the law for the transposition of the MSP Directive, Republic of Cyprus, 'Law on Maritime Spatial Planning and other relevant issues', Law 144(I)/2017 <http://www.cylaw.org/nomoi/ arith/2017_1_144.pdf > accessed on 4 April 2018.

84 Décret $\mathrm{n}^{\circ} 95^{-1232}$ du 22 novembre 1995 relatif au comité interministériel de la mer et au secrétariat général de la mer, Version consolidée au 16 septembre 2014, <https://www .legifrance.gouv.fr/affichTexte.do;jsessionid $=3 \mathrm{~A}_{42} \mathrm{EFooCD}_{3} \mathrm{D}_{4} \mathrm{ED}_{34} \mathrm{EF}_{9} 8 \mathrm{D}_{7} \mathrm{~F} 398 \mathrm{Co} 213$ .tpdjo15v_1?cidTexte=LEGITEXToooo05619885\&dateTexte=20140916 $>$ accessed on 19 September 2017 .

85 E Olsen and others, 'Integration at the Round Table: Marine Spatial Planning in MultiStakeholders Settings' (October 2014) 9 (10) PLOS ONE 2, <www.plosone.org> accessed on 10 November 2016.

86 See article 1 of the 2012 Royal Decree, Royaume de Belgique, Arrêté royal du 12 novembre 2012 relatif à l'institution d'une commission consultative et a la procédure d'adoption d'un plan d'aménagement des espaces marins dans les espaces marins belges, <http:// www.etaamb.be/fr/arrete-royal-du-13-novembre-2012_n2012024371.html > accessed on 10 November 2016. For certain issues (e.g. fisheries which is a Flemish competence) consultations among federal and Flemish authorities were conducted at ministerial level. E Olsen and others (n 85) 3 .

87 See Law 4150 [2013] J A/102, <http://www.nee.gr/downloads/261N4150-2013.pdf > accessed on 18 May 2017. 
the MSP Directive) which was already in charge of the terrestrial spatial planning. The Ministry of Environment and Energy cooperates with other ministries, primarily through consultations among relevant directorates. ${ }^{88}$

The second step for national MSP authorities is the initiation of open public participation processes, in order to convey information to interested parties (one-way information flow) and to receive feedback from the public via public hearings, submission of written comments or questionnaires (see discussion above).

\subsubsection{Transboundary Intergovernmental Consultations}

Transboundary consultations of an intergovernmental character are primarily used for the development of national MSPs. In Belgium, legislation introduced in 2012, provides for MSP information and consultation processes involving the Netherlands, France, the United Kingdom and any other countries, if considered necessary. 89

In Sweden, transboundary consultations were used as a tool for preliminary talks on MSP. The Swedish Agency for Marine and Water Management (SwAM) convened an intergovernmental consultation on Marine Spatial Planning in 2013 with the participation of all Baltic Sea countries in order to identify 'counterparts for discussing transboundary MSP issues. ${ }^{90}$ In May 2017, after the Swedish draft spatial plans for the Gulf of Bothnia, the Baltic Sea and the Skagerrak and Kattegat region were released, SwAM consulted neighboring countries. ${ }^{91}$

In Germany, public participation also took place during the preparation phase of the spatial plans for the German EEz in the North Sea and the Baltic Sea in 2008. It consisted of the publication of the draft spatial plans and environmental reports, and the organization of oral hearings, the first round of which were conducted with bordering states and the second round which were conducted with the German authorities and the public. The initial draft of the Spatial Plans for the German Eez in the North Sea underwent modest

88 See European MSP Platform, 'Maritime Spatial Planning Country Information, Greece (August 2018)' <https://www.msp-platform.eu/sites/default/files/download/ greece_31.08.2018.pdf > accessed on 2 October 2018.

89 In the Royal Decree of November 2012 (n 86) article 5.

9o See M Matczak and others, Handbook on Multilevel Consultations in MSP (PartiSEA pate 2014), 36 <http://www.partiseapate.eu/wp-content/uploads/2014/og/PartiSEApate_ handbook-on-multilevel-consultations-in-MSP.pdf> accessed on 20 September 2017.

91 Swedish Agency for Marine and Water Management, 'Sweden and Marine Spatial Planning' < https://www.havochvatten.se/en/swam/eu--international/marine-spatial -planning.html $>$ accessed ${ }_{15}$ December 2017. 
changes after the conclusion of this process. ${ }^{92}$ Consultations with bordering states concerning the draft German spatial plan for the Baltic Sea have resulted in the inclusion of two new priority areas for navigation in the Baltic Sea (south of Adlergrund shipping route between Swinemünde (Swinoujscie) and Ystad. ${ }^{93}$

Transboundary consultation is also used for the development of regional MSPS, as in the case of the Trilateral Wadden Sea Plan. The tripartite cooperation developed jointly by Germany, the Netherlands and Denmark, launched in the late 70 , is aimed at the protection of the ecological unity of the Wadden Sea. It was inaugurated with the adoption of the Joint Declaration on the Protection of the Wadden Sea in 1982. This was used as the basis for the coordinated development of MSP activities in relation to ecosystem and biodiversity protection through the prioritization of 'the protection of the Wadden sea region as a whole .... The Declaration was updated in 2010 making explicit reference to Integrated Coastal Zone Management and MSP activities which had been incorporated into the Wadden Sea Plan adopted in 1997. Political leadership and decision-making authority is vested in the Trilateral Sea Governmental Council (TSGC), which consists of the competent Ministers of the respective states and the Wadden Sea Board (WSB), with the participation of senior officials of the competent ministries or representatives of the decentralized governments from the participating states). The TSGC is convened every three years and, since the Wadden Sea tripartite cooperation is based on a political agreement, the decisions adopted appear in the form of political documents and declarations. ${ }^{94}$

92 See European msp Platform, Federal Maritime and Hydrographic Agency, 'Spatial Plan for the German Economic Exclusive Zone in the North Sea, attachment to Ordinance on Spatial Planning in the German Exclusive Economic Zone in the North Sea (Awz Nordsee-ROv) of September 21st 2009', <https://www.msp-platform.eu/practices/ maritime-spatial-plan-german-eez-north-sea> accessed on 2 October 2018.

93 See European msp Platform, Federal Maritime and Hydrographic Agency, 'Spatial Plan for the German Economic Exclusive Zone in the Baltic Sea, attachment to Ordinance on Spatial Planning in the German Exclusive Economic Zone in the Baltic Sea (Awz Baltic Sea-ROv) of December 1oth 2009', <https://www.msp-platform.eu/practices/strategic -environment-assessment-german-eez-baltic-sea $>$ accessed on 2 October 2018.

94 See Trilateral Wadden Sea Cooperation, Joint Declaration on the Protection of the Wadden Sea, 9 th December 1982 and Sylt Declaration and 2010 Joint Declaration, 11th Trilateral Governmental Conference on the Protection of the Wadden Sea, Westerland/Sylt 18 March $2010<$ http://www.waddensea-secretariat.org/trilateral-cooperation/organisationalstructure $>$ accessed on 14 February 2017. In 2012 a Communication Strategy was adopted in order to 'ensure a precise (as regards content), topical, transparent, and successful internal and external communication' and enhance in this way public support for the protection of the Wadden Sea. Trilateral Wadden Sea Cooperation, Trilateral Wadden Sea Cooperation Strategy. Communication Guidelines (May 2013) < http://www.waddensea-secretariat 
Another example is the work carried out by the working group for MSP in the Baltic established in 2010 by HЕLсом and the Vision and Strategies around the Baltic Sea (VASAB) Committee on Spatial Planning and Development of the Baltic Sea Region (CSPD/BSR). Membership in this working group comprises representatives from respective ministries of the HELCOM and VASAB contracting/member states or experts delegated by the latter. The working group is expected, inter alia, to prepare proposals on transboundary MSP, to be discussed in the Ministerial Meetings of the two institutions. ${ }^{95}$ The guidelines adopted in 2016, provide for 'cooperation between MSP authorities at pan-Baltic scale.... as well as ... effective stakeholder engagement at a more strategic level. ${ }^{96}$ Public participation is defined, in the guidelines, as 'the process by which an organization consults with interested or affected individuals, organizations, and government entities before making a decision [... It is considered as] a two-way communication and collaborative problem solving with the goal of achieving better and more acceptable solutions. ${ }^{97}$

Finally, bilateral transboundary consultation on an ad hoc basis may also provide for MSP cooperation prospects as in the case of the Memorandum of Understanding signed between Portugal and the Republic of Cabo Verde. ${ }^{98}$

\subsubsection{Transnational Consultations}

Resort to transnational consultations is not a rare phenomenon in the MSP domain. Transnational consultations transcend the intergovernmental model of deliberations, where, apart from government representatives or administration officials, NGOS, companies and experts from different countries participate. There are two types of transnational consultations. The first are those that combine the participation of state and non-state agents, such as the EU consultation processes on relevant legislation and policy documents. The second type is restricted to non-governmental participants focusing on a specific

.org/sites/default/files/downloads/twsc_com_guidelines_single_pages_2013_may.pdf> accessed on 12 September 2017.

95 HelCom-VASAB, 'Mandate for the Joint Helcom-Vasab Maritime Spatial Planning Working Group', HELCOM HOD 50-2016/72nd VASAB CSPD/BSR Meeting.

96 Baltic Marine Environment Protection Commission (n 49) 2.

97 Ibid.

98 Memorando de Entendimento entre es Governos da República Portuguesa e da República de Cabo Verde Relativo ao Programa Estratégico de Cooperação para o quinquénio 2016-2020 <http://www.instituto-camoes.pt/images/cooperacao/me_ptcv_jan2016.pdf> accessed on 17 September 2017. 
ecoregion. ${ }^{99}$ The Nordic Marine Think Tank, a network strictly reserved to the participation of experts in marine and fisheries issues and international cooperation, constitutes an example of the second type of transnational consultations on MSP. ${ }^{100}$ Another example is the Wadden Sea Forum (WSF) established under the Wadden Sea tripartite cooperation. WSF is open to the participation of all key stakeholders 'so that scientists, policy-makers, resource-users and conservationists can contribute to the Strategy and Programme of the Cooperation.101 In both cases, the systematic engagement in deliberations concerning specific issues and policies affecting an ecoregion contributes to the construction of (eco) regional transnational identities founded on the perception of maritime space as an item of the common (in terms of locality) pubic sphere. ${ }^{102}$

MSP public participation is founded on the normative legacy of the environmental domain. Due to its comprehensive character, however, MSP contributes to the spill-over of the fundamental conceptual premises of transparency, public trust and social ownership to other maritime policy domains, especially those of an economic nature. In practice, this means broadening the spectrum of stakeholders already involved in environmental public participation processes as well as the agenda of the issues on which consensus should be pursued in order to ensure the social legitimization and sense of ownership needed for the successful conduct of MSP.

The plurality of issues dealt with in MSP ventures, as well as the increase of interested parties, has an impact on the way (good) ocean governance is perceived. The role of the state remains central, but its decision-making power

99 See Andreas Klinke, 'Democratizing Regional Governance: Public Deliberation and Participation in Transboundary Ecoregions' (2012) 12 Global Environmental Politics 3, 79.

100 The Nordic Marine Think Tank published proposals on an international process in decision-making in potential MsP ventures in the Nordic area. See The Nordic Marine Think-Tank, 'Proposal for improving Decision-making management procedures in environment and fisheries Cost - efficiency - democracy in selected procedures in Maritime Spatial Planning (25 January 2015)' <http://www.nmtt.org/images/documents/ topics/2014\%2omsp/proposal\%2020150123.pdf > accessed 17 September 2017.

101 Common Wadden Sea Secretariat, 'Wadden Sea Forum' <http://www.waddensea -secretariat.org/management/the-wadden-sea-forum> accessed 19 December 2017.

102 Thomas Risse, A Community of Europeans? Transnational Identities and Public Spheres (Cornell University Press, 2010). 
seems to be eroded since the primacy of consultations among competent authorities at the national level or interstate negotiations at the international level is tempered by the logic of continuous and multilevel societal dialogue introduced by MSP. Thus, public involvement in MSP, in line with the ecosystem approach, contributes to the shift from the (inter)governmental logic of maritime governance or the realist perception of power-sharing among governmental actors, where states act as the main protagonists, to a more participatory perception of management of ocean affairs, including, apart from states, other actors such as international organizations, advocacy groups, ocean users and individuals.

This is accentuated by a number of factors. First, the high degree of specialization of international maritime relations and its reliance on scientific or technocratic expertise constrains the political rhetoric of governmental agencies. Second, the transboundary nature of maritime affairs, as well as the discussion on the prospects of MSP in areas beyond national jurisdiction, brings to the fore the role of international institutions which already serve as an MSP agora, ${ }^{103}$ providing the political environment for deliberations among governmental but also non-state actors. Third, the prioritization of growth-oriented uses of the marine space vis à vis environmental protection as depicted in the EU approach, as well as the impact of the recent global financial crisis, seem to further enhance the role of market stakeholders in public (often informal) MSP consultations.

Additionally, the linkage of MSP to the fulfillment of the Sustainable Development Goals set by the UN Agenda 2030 during the 2017 UNESCO-EU workshop may further enhance the logic of public participation moving from consensus-seeking to the creation of multi-stakeholder partnerships in line with Sustainable Development Goal $17 \cdot{ }^{104}$ Such partnerships could further

103 According to Klabbers, international organizations functions as a classical public agora, 'a public realm in which international issues can be debated and, perhaps, decided', J Klabbers, 'Two concepts of international organization' (2005) 2 International Organization Law Review 277, 282.

104 Sustainable Development Goal 17 'Revitalize the global partnership for sustainable development' is intended to promote 'inclusive' partnerships between governments, the private sector and civil society which 'built upon principles and values, a shared vision, and shared goals that place people and the planet at the centre, are needed at the global, regional, national and local level'. The aim of the specific target on Multi-stakeholder partnerships is to '[e]ncourage and promote effective public, public-private and civil society partnerships, building on the experience and resourcing strategies of partnerships'. United Nations, 'Sustainable Development Goals' <http://www.un.org/sustainable development/globalpartnerships/> accessed on 19 September 2017. 
enhance the decentralization or even the delegation of certain management processes, thereby enhancing public participation in actual decision-making. However, it seems that we are still far from a post-political condition in MSP where rational consensus-building and/or hybrid partnerships among governmental and non-state agents will guide decision-making. ${ }^{105}$

\section{Table of Authorities}

\section{Treaties}

Convention on Biological Diversity [1992] 1760 UnTS 79.

Convention on Access to Information, Public Participation in Decision-Making and Access to Justice in Environmental Matters (Aarhus Convention) [1998] 2161 UNTS 447 .

\section{EU Legislation}

European Parliament and Council Directive 2014/89/EU of 23 July 2014 establishing a framework for maritime spatial planning [2014] OJ L 257/135 (MSP Directive).

European Parliament and Council Directive (EU) 2014/52/EU of 16 April 2014 amending Directive 2011/92/EU on the assessment of the effects of certain public and private projects on the environment [2014] OJ L 124/1.

European Parliament and Council Regulation (EC) 1367/2006 of 6 September 2006 on the application of the provisions of the Aarhus Convention on Access to Information, Public Participation in Decision-making and Access to Justice in Environmental Matters to Community institutions and bodies [2006] OJ L 264/13.

European Parliament and Council Directive (EC) 2003/35/EC providing for public participation in respect of the drawing up of certain plans and programmes relating to the environment [2003] OJ L 156/17.

European Parliament and Council Directive (EC) 2003/4 of 28 January 2003 on public access to environmental information and repealing Council Directive 90/313/EEC [2003] OJ L 41/26.

European Parliament and Council Directive (EC) 2001/42 of 27 June 2001 on the assessment of the effects of certain plans and programmes on the environment [2001] OJ L 197/30 (SEA Directive).

105 See RV Tafon, 'Taking Power to Sea: Towards Post-structuralist Theoretical Critique of Marine Spatial Planning' (2017) 36(2) Environment and Planning C: Politics and Space 258 . 


\section{Bibliography}

\section{Books}

Almond GA and Verba S, The Civic Culture. Political Attitudes and Democracy in Five Nations (Sage 1963).

Chang Y-C, Ocean Governance (Springer Briefs in Geography 2012).

Edward Freeman R, Strategic Management: A Stakeholder Approach (1984, reprinted by Cambridge University Press 2010).

Fischer F and others (eds), Handbook of Public Policy Analysis. Theory, Politics and Methods (CRC Press Taylor \& Francis Group 2007).

National Research Council, Public Participation in Environmental Assessment and Decision Making (The National Academies Press 2008).

Patraiko D and Holthus P, The Shipping Industry and Marine Spatial Planning. A Professional Approach (The Nautical Institute/World Ocean Council 2013).

Pomeroy R and Rivera-Guieb R, Fishery co-management. A practical handbook (CABI Publishing and International Development Research Centre 2006).

Risse T, A Community of Europeans? Transnational Identities and Public Spheres (Cornell University Press 2010).

\section{Official Publications}

Baltic Marine Environment Protection Commission, 'Guidelines on transboundary consultations, public participation and co-operation, Laulasmaa, Estonia, 15-16 June 2016', HOD 50-2016.

Commission, 'Roadmap for Maritime Spatial Planning: Achieving Common Principles in the EU' сом (2008) 791 final.

Commission, 'European Governance: A White Paper' Сом (2001) 428.

Commission, 'International ocean governance: an agenda for the future of our oceans' JoIN (2016) 49 final.

Commission on Global Governance, Our Global Neighborhood, <http://www.gdrc.org/ u-gov/global-neighbourhood/> accessed on 5 November 2016.

Federal Council for Sustainable Development $<$ http://www.frdo-cfdd.be/en $>$ accessed on 18 September 2017.

General Assembly, 'Report on the United Nations Conference on Environment and Development' [1992] A/CONF.151/26 (Vol. I), Annex I - Rio Declaration on Environment and Development.

General Assembly, 'Transforming our world: the 2030 Agenda for Sustainable Development' UNGA Res 70/1 (25 September 2015), UN Doc. A/RES/70/1.

HELCOM, 'Joint HELCOM-VASAB Maritime Spatial Planning Working Group Report 2010-2013' (2013). 
Helcom-VASAB, 'Mandate for the Joint Helcom-Vasab Maritime Spatial Planning Working Group', HELCOM HOD 50-2016/72nd VASAB CSPD/BSR Meeting.

Hellenic Republic, 'Special Planning. Sustainable Development and other provisions', Law 4447 [2016] A/241 <http://www.elinyae.gr/el/lib_file_upload/241A_ 2016.1484831674306.pdf > accessed on 20 September 2017.

Hellenic Republic-Ministry of Environment and Climate Change, 'Establishment of the National Council on Spatial Planning and Sustainable Development', Ministerial Decree of 2nd July 2010, <http://www.ypeka.gr/LinkClick.aspx?fileticket=QDw \%2B2kQwQUI\%3D\&tabid=508> accessed 19 September 2017.

Hellenic Republic, 'Ministry of Mercantile Marine and the Aegean Reform and other provisions', Law 4150 [2013] J A/102, <http://www.nee.gr/downloads/261N4150-2013 .pdf> accessed on 18 May 2017.

Intergovernmental Oceanographic Commission, European Commission - DG MARE, The 2nd International Conference on Marine/Maritime Spatial Planning, 15-17 March 2017, IOC Workshop Series 279 (UNESCO 2017).

MRAG, 'Legal Aspects of Maritime Spatial Planning', Final Report to DG Maritime Affairs and Fisheries, Framework Service Contract, No. FISH/2006/og-LOT-2, October 2008.

Portuguese Republic, 'National Ocean Strategy' (2007) <http://www.ioc-unesco.org/ images/stories/LawoftheSea/Documents/NationalOceanPolicy/nop.portugal.pdf> accessed on 2 October 2018.

Republic of Cyprus, 'Law on Maritime Spatial Planning and other relevant issues', Law 144(I)/2017 <http://www.cylaw.org/nomoi/arith/2017_1_144.pdf> accessed on 4 April 2018.

Republic of Cyprus, 'Strategy for a National Integrated Maritime Policy', <http://www .cpa.gov.cy/CPA/userfiles/documents/strategy.pdf> accessed on 18 May 2017.

République Française, Décret $\mathrm{n}^{\circ} \mathbf{9 5}^{-1232}$ du 22 novembre 1995 relatif au comité interministériel de la mer et au secrétariat général de la mer, Version consolidée au 16 septembre 2014, <https://www.legifrance.gouv.fr/affichTexte.do;jsessionid=3A42E FooCD $3 D_{4} E_{34}$ EF98D 7 F398Co213.tpdjo15v_1?cidTexte=LEGITEXTooooo5619885\& dateTexte $=20140916>$ accessed on 19 September 2017 .

République Française-Ministère de l'Écologie, de l'Energie, du Développement durable et de la Mer, 'Grenelle de la mer: vers un renouveau de la politique maritime?' $<$ http://www.vie-publique.fr/actualite/dossier/grenelle-mer/grenelle-mer-vers -renouveau-politique-maritime.html> accessed on 15 June 2017.

Royaume de Belgique, Arrêté royal du 12 novembre 2012 relatif à l'institution d'une commission consultative et a la procédure d'adoption d'un plan d'aménagement des espaces marins dans les espaces marins belges, <http://www.etaamb.be/fr/ arrete-royal-du-13-novembre-2012_n2012024371.html> accessed on 10 November 2016. 
The Nordic Marine Think-Tank, 'Proposal for improving Decision-making management procedures in environment and fisheries Cost - efficiency - democracy in selected procedures in Maritime Spatial Planning (25 January 2015)' < http://www .nmtt.org/images/documents/topics/2014\%2omsp/proposal\%2020150123.pdf> accessed 17 September 2017.

Trilateral Wadden Sea Cooperation, Joint Declaration on the Protection of the Wadden Sea, 9th December 1982 and Sylt Declaration and 2010 Joint Declaration, 11th Trilateral Governmental Conference on the Protection of the Wadden Sea, Westerland/ Sylt 18 March $2010<$ http://www.waddensea-secretariat.org/trilateral-cooperation/ organisational-structure $>$ accessed on 14 February 2017.

Trilateral Wadden Sea Cooperation, Trilateral Wadden Sea Cooperation Strategy. Communication Guidelines (May 2013) < http://www.waddensea-secretariat.org/ sites/default/files/downloads/twsc_com_guidelines_single_pages_2013_may.pdf> accessed on 12 September 2017.

UN Environment Programme (Mediterranean Action Plan), 'Marine Spatial Planning and the protection of biodiversity beyond national jurisdiction (BBNJ) in the Mediterranean Sea' (17 February 2017) UNEP(DEPI)/ME D WG.431/Inf.8.

UN Oceans and the Law of the Sea in the General Assembly of the United Nations, Reports of the Secretary General < http://www.un.org/depts/los/general_assembly/ general_assembly_reports.htm > accessed on 6 November 2016.

United Nations, 'Sustainable Development Goals' <http://www.un.org/sustainable development/globalpartnerships/> accessed on 19 September 2017.

United Nations, 'Report on the Work of the United Nations Open-Ended Informal Consultative Process on Oceans and the Law of the Sea at its Seventh Meeting' (July 2006) A/61/156 17 .

World Bank, 'Stakeholder Analysis', <http://www1.worldbank.org/publicsector/ anticorrupt/PoliticalEconomy/stakeholderanalysis.htm $>$ accessed on 6 November 2016.

\section{Journal Articles}

André P and others, 'Public Participation. Best Practice Principles' (August 2006) IAIA Special Publication Series 4.

Arnstein SR, 'A Ladder of Citizen Participation' (1969) 35 Journal of the American Planning Association 216.

Aynul Islam M, 'Microgovernance: A Prospective Tool of Good Governance in Bangladesh' (2007) 28 BIIss Journal 1.

Börzel TA, 'Organizing Babylon - On the different conceptions of policy networks' (1998) 76 Public Administration, 253, 260.

Brozel TA and Risse T, 'Dysfunctional State Institutions, Trust and Governance in Areas of Limited Statehood' (2016) 10 Regulation \& Governance 149. 
Calado H and others, 'Marine Spatial Planning: Lessons Learned from the Portuguese Debate (2010) 34 Marine Policy 1341.

Calado H and others, 'NGO involvement in marine spatial planning: a way forward?' (2012) 36 Marine Policy 382.

Day J, 'The need and practice of Monitoring, Evaluating and Adapting Marine Planning and Management - Lessons from the Great Barrier Reef' (2008) 32 Marine Policy 823.

DeSario J and Langton S, 'Citizen Participation and Technocracy' (1984) 3 Public Policy Review 2, 223.

Fletcher S, 'Converting science to policy through stakeholders' involvement: an analysis of the European Marine Strategy Directive' (2007) 54 Marine Pollution Bulletin 1881 .

Grisez Kweit M and Kewit RW, 'The Politics of Policy Analysis: The Role of Citizen Participation in Analytic Decisionmaking' (1984) 3 Public Policy Review 2, 234.

Guerry AD and others, 'Modeling benefits from nature: using ecosystem services to inform coastal and marine spatial planning' (2012) 8 International Journal of Biodiversity Science, Ecosystem Services \& Management 1-2, 107.

Jay S and others, 'International Progress in Marine Spatial Planning' (2013) 27 Ocean Yearbook 171.

Klabbers J, 'Two concepts of international organization' (2005) 2 International Organization Law Review 277.

Klinke A, 'Democratizing Regional Governance: Public Deliberation and Participation in Transboundary Ecoregions' (2012) 12 Global Environmental Politics 3, 79.

Lindkvist $\mathrm{E}$ and others, 'Micro level explanations for emergent patterns of selfgovernance arrangements in small-scale fisheries. A modelling approach' (2017) 12 PLOS 4: e0175532.

Mackinson S and others, 'Engaging stakeholders in fisheries and marine research' (2011) 35 Marine Policy 18.

Maes F, 'The International Legal Framework for Marine Spatial Planning' (2008) 32 Marine Policy 797.

Perkins Spyke N, 'Public Participation in Environmental Decisionmaking at the New Millennium: Structuring New Spheres of Public Influence' (1999) 26 Boston College Environmental Affairs Law Review 263.

Pomeroy R and Douvere F, 'The Engagement of Stakeholders in the Marine Spatial Planning Process' (2008) 32 Marine Policy 816.

Reed MS, 'Stakeholder Participation for Environmental Management: A Literature Review' (2008) 141 Biological Conservation 2417.

Rowe G and Frewer L, 'A Typology of Public Engagement Mechanisms' (2005) 30 Science, Technology \& Human Values 251.

Sauvée L, 'Hybrid governance: sketching discrete alternatives' (2013) 13 Journal on Chain and Network Science 1. 
Tafon RV, 'Taking Power to Sea: Towards Post-structuralist Theoretical Critique of Marine Spatial Planning' (2017) 36(2) Environment and Planning C: Politics and Space 258 .

Zervaki A, 'The Legalization of Maritime Spatial Planning in the European Union and its Implications for Maritime Governance' (2016) 30 Ocean Yearbook 32.

\section{Other Print Sources}

Ehler C and Douvere F, Marine Spatial Planning: A step-by-step approach toward ecosystem-based management, Intergovernmental Oceanographic Commission (IOC) and Man and the Biosphere Programme, IOC Manual and Guides 53, ICAM Dossier, 6 (UNESCO 2009).

Ehler C and Douvere F, Visions for a Sea Change. Report of the First International Workshop on Marine Spatial Planning. Intergovernmental Oceanographic Commission and Man and the Biosphere Programme, Ioc Manual and Guides 46, ICAM Dossier, 3 (UNESCO 2007).

\section{Internet Sources}

Boege V and others, 'On Hybrid Political Orders and Emerging States: State Formation in the Context of 'Fragility' (October 2008) Berghof Research Center for Constructive Conflict Management, <http://edoc.vifapol.de/opus/volltexte/2011/2595/pdf/ boege_etal_handbook.pdf $>$ accessed on 31 May 2017.

Carr S, 'What Role does Ocean Zoning Play in Marine Spatial Planning? Viewpoints from the EU, US and China' (2011) < https://meam.openchannels.org/news/meam/ what-role-does-ocean-zoning-play-marine-spatial-planning-viewpoints-eu-us -and-china $>$ accessed on 22 February 2018.

Commission, 'Funding MSP cross-border projects' < https://ec.europa.eu/maritime affairs/policy/maritime_spatial_planning_en $>$ accessed on 27 September 2017.

Common Wadden Sea Secretariat, 'Wadden Sea Forum' <http://www.waddensea -secretariat.org/management/the-wadden-sea-forum $>$ accessed 19 December 2017.

Cross-border Cooperation Programme 'Greece - Cyprus 2007-2013' <http://www .mspcygr.info/> accessed 17 September 2017.

Douvere F, Marine spatial planning: Concepts, current practice and linkages to other management approaches (Ghent University Belgium 2010) <https://biblio.ugent.be/ publication/8509486/file/8509487.pdf > accessed on 18 May 2017.

European Ms P Platform, Federal Maritime and Hydrographic Agency, 'Spatial Plan for the German Economic Exclusive Zone in the North Sea, attachment to Ordinance on Spatial Planning in the German Exclusive Economic Zone in the North Sea (AWZ Nordsee-ROv) of September 21st 2009' <https://www.msp-platform.eu/practices/ maritime-spatial-plan-german-eez-north-sea $>$ accessed on 2 October 2018. 
European MSP Platform, Federal Maritime and Hydrographic Agency, 'Spatial Plan for the German Economic Exclusive Zone in the Baltic Sea, attachment to Ordinance on Spatial Planning in the German Exclusive Economic Zone in the Baltic Sea (Awz Baltic Sea-ROv) of December 10th 2009' < https://www.msp-platform.eu/ practices/strategic-environment-assessment-german-eez-baltic-sea $>$ accessed on 2 October 2018.

European MsP Platform, 'Maritime Spatial Planning Country Information, Greece (August 2018)' <https://www.msp-platform.eu/sites/default/files/download/greece 31.08.2018.pdf $>$ accessed on 2 October 2018.

European MSP Platform, 'Maritime Spatial Planning Country Information, Portugal (November 2017)' <https://www.msp-platform.eu/sites/default/files/download/ portugal_02.11.2017.pdf> accessed 25 September 2018.

Federal Maritime and Hydrographic Agency, 'Federal Government's provider of maritime services' <http://www.bsh.de/en/Products/Information_material/BSHFlyer .pdf $>$ accessed on 17 September 2017 .

Hellenic Republic - Ministry of Environment and Energy, 'Consultation site' <http:// www.opengov.gr/minenv/?p=8366> accessed on 18 December 2017.

Lee $\mathrm{M}$, 'The Legal Institutionalization of public participation in the EU governance of technology' (June 2014) ECPR Regulatory Governance Conference <https://papers .ssrn.com/sol3/papers.cfm?abstract_id=2461145> accessed on 2 October 2018.

Matczak M and others, Handbook on Multilevel Consultations in MSP (PartiSEApate 2014), 36 <http://www.partiseapate.eu/wp-content/uploads/2014/og/PartiSEApate_ handbook-on-multilevel-consultations-in-MSP.pdf> accessed on 20 September 2017.

Memorando de Entendimento entre es Governos da República Portuguesa e da República de Cabo Verde Relativo ao Programa Estratégico de Cooperação para o quinquénio 2016-2020 <http://www.instituto-camoes.pt/images/cooperacao/me ptcv_jan2016.pdf $>$ accessed on 17 September 2017.

Olsen E and others, 'Integration at the Round Table: Marine Spatial Planning in MultiStakeholders Settings' (October 2014) 9 (10) PLOS ONE 2, <www.plosone.org> accessed on 10 November 2016.

Swedish Agency for Marine and Water Management, 'Sweden and Marine Spatial Planning' < https://www.havochvatten.se/en/swam/eu--international/marine-spatial -planning.html > accessed on 15 December 2017.

Unesco, '2nd International Conference on Marine Spatial Planning' <https:// en.unesco.org/events/2nd-international-conference-marine-spatial-planning> accessed on 10 December 2017.

Vassilopoulou V and others, Declaration on the Development of Maritime Spatial Planning in Greece, adopted within the framework of the nth Panhellenic Symposium on Oceanography and Fisheries, organized by the Hellenic Centre for Marine Research 
and the University of the Aegean, Lesvos, May 2015, <http://www.symposia.gr/wp -content/uploads/2015/o6/MSP_declaration_web.pdf > accessed on 2 September 2017.

Veidemane K, 'Stakeholder involvement in development of the Maritime Spatial Plan of Latvian waters' (2015), <https://www.bonusportal.org/files/4063/Kristina Veidemane_Baltic_Environmental_Forum_Latvia.pdf $>$ accessed on 18 December 2017. 